\title{
FEMALE ROLES IN LA CINTA DORADA BY MARÍA MANUELA REINA AND MODELS OF THE WORLD
}

\author{
Ana María Aguilar López \\ https://orcid.org/0000-0002-1506-9823 \\ Scopus Author ID: $\underline{55754069100}$ \\ amaguilar@ubu.es \\ University of Burgos, Spain \\ Marta Miguel Borge \\ https://orcid.org/0000-0002-6381-5384 \\ mmborge@ubu.es \\ University of Burgos, Spain
}

Received March 27, 2021; Revised May 28, 2021; Accepted June 4, 2021

\begin{abstract}
Our model of the world that we perceive within ourselves, our conscience, in short, our psychological balance is influenced by our surroundings. Part of the input to which we are exposed in this immediate environment is related to texts, self-managed discourse, which can also influence our internal model of the world; hence they are deserving of our attention. In the same way as the models of the world that we construct throughout our lives, reality is not static and also changes as time goes by. From a social point of view, we can see that the roles of women in modern-day society and the ways that those roles can be perceived today are a consequence of changes initiated in the past within different areas and in a prolonged process over time up until our day. With the aim of evaluating whether female drama has contributed to that change, we present an analysis in this paper of the play La Cinta Dorada [The Golden Ribbon] by María Manuela Reina, written and set in the 1980s, a decade that for Spain implied a more obvious abandonment of the most traditional conceptions of the role of women. In the analysis of the play, we see how the models of the world of the older people are counterposed with those of the younger people, a generational divide that is enriched with the gender difference, as we also analyze how the psychological structures of the female and male characters confront the clichés pertaining to another era in reference to such topics as success, infidelity, matrimony, and gender. The results of our analysis demonstrate how Reina responds to archaic conceptions, thereby inciting the audiences of the day to question their respective models of the world, especially, with regard to the role of the woman in society.
\end{abstract}

Keywords: psychology of language, inference, model of the world, Spanish dramaturgy, María Manuela Reina, female character, La Cinta Dorada.

Лопез Ана Марія Агіляр, Борге Марта Мігель. Жіночі ролі у «Золотій стрічці» Марії Мануели Рейни та моделі світу.

Анотація. Навколишній світ чинить уплив на сприйману нами модель світу й на нашу психологічну рівновагу. Частина інформації, якій ми піддаємось у цьому безпосередньому

(C) López, Ana María Aguilar; Borge, Marta Miguel, 2021. This is an Open Access article distributed under the terms and conditions of the Creative Commons Attribution 4.0 International Licence (http://creativecommons.org/licenses/by/4.0).

East European Journal of Psycholinguistics, 8(1), 41-56. https://doi.org/10.29038/eejpl.2021.8.1.agu 
світі, пов'язана з текстами, самокерованим дискурсом, який також може впливати на нашу внутрішню модель світу. Саме тому всі вони заслуговують на нашу увагу. Подібно до моделей світу, які ми будуємо протягом усього життя, реальність не є статичною й зазнає змін із плином часу. Із соціального погляду, ми можемо побачити, що ролі жінок у сучасному суспільстві та способи сприйняття цих ролей сьогодні $\epsilon$ наслідком змін, започаткованих у минулому в різних сферах, та наслідком тривалого процесу цих змін до наших днів. 3 метою оцінки того, чи мала ця зміна вплив на жіночу драму, автори представляють у цій праці аналіз вистави «Золота стрічка» Марії Мануели Рейни, написаної та поставленої на сцені у 1980-х роках. Це десятиліття відзначено для Іспанії очевидною відмовою від найбільш традиційних уявлень про роль жінки. Під час аналізу п'єси простежуємо, як моделі світу старших людей протиставляються моделям молодших людей, бачимо різницю поколінь, що збагачується різницею статей. Також аналізуємо, як психологічні структури жіночих і чоловічих персонажі стикаються 3 традиційними уявленнями, що стосуються іншої епохи, щодо таких тем, як успіх, зрада, подружжя та стать. Результати нашого аналізу демонструють те, як Марія Мануела Рейна відповідає на архаїчні уявлення, спонукаючи тим самим тогочасну аудиторію до сумнівів у своїх моделях світу, особливо щодо ролі жінки в суспільстві.

Ключові слова: психологія мови, умовивід, модель світу, іспанська драматургія, Марія Мануела Рейна, жіночий персонаж, Золота стрічка.

\section{Introduction}

Following the Vygotskian school of thought, the concept of the conscience consists of higher psychological processes that flow from our interactions with the environment in which we are immersed, Cantero \& de Arriba (1997) considered that this conscience was equivalent to the representation that the individual has formed of reality. It is therefore partial and unlike that of other individuals, given that each of us form a representation of the world on the basis of the particular perceptions of what we see around us, of what we have experienced. This situation provokes the apparent paradox that, despite there being one reality, each person has a personal model of the world. For Cantero \& de Arriba (ibid.) the model that each one of us has of reality or of the world, in short, our psychological structure, is determined by "the cultural framework in which we have grown up: the attitude, the traditions, the points of view that have been imposed on us (as individuals) and the skills that we have developed since childhood" (p. 91), from which we can infer that the cultural framework might explain if not all, at least some of the different conceptualizations of the world that individuals can generate.

However, what is the role of language, more specifically verbal language, in all this?

For the same authors (ibid.), the word that is the principal unit of linguistic analysis, is also, in turn "the principal element in the formation of the conscience, in the conception of reality, in the transfer of knowledge and in the regulation of behavior" (p.58), such that, in their opinion, it justifies that the word can also be turned into the unit of psychological analysis.

We can consider the word as a unit of psychological analysis, because language makes it possible to interact with others, with our surroundings, ruling our 
thoughts, and shaping the subjective vision that we have of the world; in such a way that, thanks to language, the development of conscience is possible. It can be perceived as a sort of mediator between the model of the world that we shape and the reality that surrounds us. Our production of speech, the language that we pronounce, our discourse, also reflect a vision, the model of the world that we have configured within ourselves at any one time. Cantero \& de Arriba (1997) pointed out that language is "the mediator between reality and our model of the world and between our model of the world and our discourses" (p. 103). As Acuña \& Adames (2020) pointed out, the relation between knowledge of the world and language is such that, our knowledge of the world can be of influence, beyond lexical questions, in relation to the syntactic structure of what we say.

The models that each one of us devises of the world are dynamic. In other words, they vary over time, they are shaped throughout the process of life and not only are our experiences of what surrounds us woven into them, but so too are the confrontations with the models of the world that other people have constructed for themselves.

As if it were a reflection of reality, we can observe this process on a smaller scale, in literary texts. These are imbued with greater complexity than spontaneous oral communication, in which the reader must establish the cohesion and the coherence of each text. Employing knowledge of the world, the reader must undertake a series of inferences and thereby construct appropriate situational models (Cuetos, González, \& de Vega, 2020).

For García Barrientos (2017). in the same way as in other sorts of discourse, in theatrical works the characters are not normally living "with their backs to the world of meaning. Directly or indirectly, they must keep some sort of relation with the theatrical work, as even the most frivolous or non-transcendent work contains an idea of reality, a model of the world." (p. 159). Based on these words, we can deduce that theatrical works give us intuitive insight into the model of the world that the dramatists are at least suggesting to us that they have, (which can be seen through the selection that they make of the situations that they wish to bring to the scene, the way in which the people act and express themselves, etc.). Although as receptors of the text, not only can we deduce the vision of the world that the author is proposing, through theatre, we can also contrast new models of the world with those that are acted out on stage and, from the confrontation, the comparison with that reality that is presented to us, we can modify our awareness, or what is the same, our perception of the world, our mental schemes of what reality is or could be. Hence the enormous power and responsibility of the dramatist.

Precisely because of our awareness of the importance that dramatists have in the creation of a social conscience that is capable of transforming the society in which we are living, this work is centred on the analysis of a very specific type of discourse: a theatrical work. Although it is true that this possibility of confronting our mental schemes about the world with those arising in texts is also consubstantial with other sorts of literary texts, the theatrical text has the particularity that discourse can always come to life and insert itself as yet another piece of reality in 
the world. That is its final aim, so that it can directly reach an audience in an immediate manner, without the mediation of reading.

In addition, in this work, we seek to adhere to the current trend of bringing to the forefront and recognizing the contribution that, throughout time immemorial, women have made to different fields of knowledge. That is the reason why, in particular, we wish to know whether female dramaturgy, from the inherent responsibility of exercising its own profession, has sought to contribute and, if that is so, how, female dramaturgy has influenced changes to the roles that women play in modern-day society, as well as the perceptions of women that are prevalent today.

However, in view of the vast expanse of this field, some boundaries must be established, for which reason we will focus our attention on the play La Cinta Dorada [The Golden Ribbon] (1989) by the dramatist María Manuela Reina.

\section{Justification of the choice: background context of the play}

The time at which this play was penned coincided with a second wave of feminism in the international arena that called for a review of the role of women in such areas as the family, work, sexuality, and abortion.

In Spain, after a dictatorship of over 30 years (from 1939 to 1975), during which ideas of a conservative nature prevailed that quite clearly relegated women to a domestic role, a period of democratic transition followed that brought with it some decisive measures that were to change the role that women played within society. Thus, the Civil Code was reformed in 1981, in recognition of legal equality between men and women within marriage, which meant that a woman no longer had an obligation to obey her husband who was dispossessed of the authority over his wife that had earlier been accorded to him. Likewise, the Divorce Law was enacted in the same year that implied complete liberation for many couples.

In 1982, social change continued under the government of Felipe González, who governed from that year up until 1996. Some of these changes turned out to be decisive for many women, such as the legalization of abortion in circumstances involving rape, foetal malformation, and risks to the mother.

These legal changes in social matters were accompanied by others such as the access of women to posts of responsibility formerly reserved for men, the earlier age of marriage and the reduction in the number of offspring that women were accustomed to having.

La Cinta Dorada (1989) takes place in the socio-political context that we have outlined above when the dramaturgy of Spanish authors alive to those times were claiming a greater on-stage presence in the panorama of Spanish theatre, especially commercial theatre, as they perceived a clear tendency towards the theatrical production of classic Spanish or foreign texts, a circumstance which relied upon institutional support. It led them to the constitute an association in 1990, the Association of Theatre Authors [Asociación de Autores de Teatro] (AAT). They sought to make known the dramaturgical panorama that existed in Spain at that time, publishing their plays and encouraging their production on stage. At the same 
time, they came together to call for more funding from the administration and greater support from institutions. Although their absence from commercial theatre was not only attributable to institutions, the playwright Lourdes Ortiz pointed to the theatre directors of the day, saying that "they don't dare or it doesn't occur to them to pick up a text that isn't mainstream and neither do the actors." (Cabal, 1982, p. 58).

The impossibility of having their plays presented on stage invalidated that previously mentioned option of creating social awareness and of doing so with the immediacy that formal theatre enjoys. Thus, we understand that the dramaturgy of Spanish authors living through those years (end of the 1980s - start of the 1990s) was very clear that its works were a commitment to their times, a reflection of what they saw around them, a critique and a vindication on the stage from and for their present-day reality, despite the obstacles to reaching the general public that they encountered. In the opinion of Sánchez Martínez (2005), the dramatists of the 1990s directed "their gaze towards the individual conflict, seeking the authenticity of values, of society, and they proposed a vision of the world in which the differences between ideals and the surrounding reality were recognized" (p.42).

The dramatists of that time were aware of the difficulty of producing their work and all the more so in commercial theatres. They also criticized the fact that if plays from living playwrights were welcomed in those theatres, they were invariably from the most celebrated authors. A situation that prompted reflections among the youngest dramatists of the day such as Ortiz de Gondra, who asked: "is the public conservative or is it what they're fed?" (Matteini, 1997, p. 13).

More experienced dramatists such as Paloma Pedrero went a step further when proposing the existence of another factor to take into account in the dramaturgical panorama of the day: the gender of the writer. They affirmed that: "The theatre world in Spain, and above all in commercial theatre, is of quite an old age, so the people appraising your work are too old and, in addition, they're men." (Ortiz, 1995, p. 12).

However, María Manuela Reina was not only awarded many prizes for her theatrical works, which contributed to their wider circulation, but in addition she herself produced a lot of her works in comparison with other contemporary dramatists, and in large theatres, through which she was able to gain wider access the general public, hence our reasons for having selected her drama.

With regard to the choice of this particular work, we have to say that, although María Manuela Reina included female characters in all of her works, in this play we found a constant dialogue between some mental schemes germinating in the masculine world and the feminine mental schemes that rebel against the former. In that dialogue, the younger people, regardless of their gender, have the opportunity of influencing and, therefore, of modifying the representations of the world of the older generations. In addition, we can see how a sorrowful situation experienced by the leading female character, Adi, has shaped her. In other words, how it has influenced her conscience, the construal of her psychological structure and the perception that she has of the role of women and men in society. 


\section{Method}

As we have pointed out, our sample or unit of analysis is the drama The Golden Ribbon by María Manuela Reina. The principal objective of our analysis is to determine whether this dramatist, exploiting the opportunity that she had to reach out to the general public of her day with an immediate discourse and the inherent possibility in her profession of a dramatist creating social awareness, gave a voice in her play to the female world. And, by so doing, to the critique of women who rebelled against the social role that they were assigned in the more inflexible masculine, although also feminine world, and, that being so, to identify how the dramatist managed to do so, and what she said through the characters.

Having delimited the object of study, following Santander (2011), when approaching discourse analysis, we must be clear that not only the problem, but also the questions of the research hypothesis that we advance are of a discursive nature, as, on the contrary, the analysis of the text might be senseless.

We have set out questions that arise, as is logical, from the very objectives of the research and that can guide the analysis. These questions are: in the Golden Ribbon, how far does María Manuela Reina capture the feeling of women who cannot accept the social roles that they have traditionally been assigned? In the same play, what kinds of women's' voices does María Manuela bring to life? Do they embody some sort of stereotype? Are these stereotypes interrupted, and if so, at what point and how do they appear?

These questions will give us the chance to sketch out a path for the analysis of the text. However, that general plan might undergo modifications, given that we wish this study to have more of an open qualitative design, less directed than a quantitative one, in order to respond to those research questions.

We are thinking of a qualitative type of design, because, as Hernández, Fernández, \& Baptista (2010) pointed out, it is through this type of design that we can learn about the points of view and the experiences of people. The associations with an interpretative and inductive research process, likewise, appear to us to be more in accordance with our objectives and research questions.

Having outlined the context in which the work is set -pertaining to and necessary for a qualitative study- we lend special attention to annotations of an interpretative and thematic type for its analysis, which have emerged during the readings. We do so as we seek to conduct an analysis of the spoken words of the characters that is oriented towards the meaning of the discourse and not of its grammar. For Gracía Barrientos (2017), the fact of relating the characters with the meaning of the play "implies examining the possible symbolic, ideological values, and in short the semantics that they may (or may not) support as an additional load, beyond their strictly representative role; which is, to inquire into what such and such a character means in addition to what that character might represent" (p. 159); according to this author, we must also be aware that there are more or less semanticized characters, or what amounts to the same thing, characters with greater levels of meaning, more neutral, on which basis it is more difficult to make a significative generalization. 
Through character discourse analysis, we seek to identify concepts and variables that constitute the units of analysis to which we arrive after structuring the data. We do so because, as Hernández et al. (2010) mentioned, in qualitative studies, the "essential process of the analysis consists of our receiving non-structured data that we then structure" (p. 440). It is therefore our work to infer similitudes and differences between the data that constitute each unit of analysis, to describe the experiences of the characters of the play, to identify topics, to explain situations etc. We can therefore affirm that the design of our investigation was principally conceived with a descriptive and an exploratory end in sight.

In addition, our design has a temporary scope of a synchronic or sectional type, as it is based on the analysis of a single play of a dramatist through which we can approach the ideas that the dramatist held on the world at the time that she was writing; with regard to its amplitude, we can consider it a micro-sociological design, because the size of the sample that is analyzed converts it into a case study. Precisely because this play is the source of the data under investigation, we are undertaking an investigation with secondary data, which is to say, data that are used in rather than created for the investigation.

\section{Results and Discussion}

\section{Analysis of the play}

In The Golden Ribbon, a complete family reunion is brought to the stage. The pretext behind such an event is the birthday of the father, Edward, an occasion for which his four grown-up children (Ramon, Javier, Ernest, and Adela, shortened to Adi) are there to celebrate. Beneath this apparently cosy scene from daily life, there is another event, its roots sinking deep into the shared past of the three brothers, that goes back to the tenderest youthful age of Adi who became pregnant as a consequence of a relation with one of her brothers. She had little choice other than to terminate her pregnancy behind closed doors, exposing herself to the opprobrium and the reproachful looks of those who were unaware of the true story. The siblings entered into a pact, never to tell a soul, inventing a story between each other that might be convincing and that could account for and explain how the events had taken place. However, Edward, their father, never believed the tale that his children had woven and always suspected that one of them had fathered the baby of his daughter.

The play, divided into five scenes, all takes place over a weekend in March 1988, although in the beginning and at the end of the play there is a jump of twelve years into the future.

\section{Two generations, two profiles of women}

From the outset, Adela stands out as a young woman, authentic, of her day, willing to break with stereotypes, competent, beautiful, efficient and, apparently, 
quite cold, although it all appears to be a consequence of the harm that has been done to her. She tells her mother: "I don't let people hurt me anymore", to which Emilia answers: "And is that enough, saying that to yourself? How lucky you are!", Adi explains to her mother how she does so: "There are rules that give results: don't trust anyone, get what you want and escape; renew everything each season, clothing, friends, lovers... and run away anywhere as soon as you suspect that you might want to return." (Reina, 1989, p. 75).

For her, men are a toy with whom to entertain herself all the time and she seeks no more than that. She tells her father: "You taught me to expect so much from men, that they didn't appear remotely like you or my brothers. I don't ask anything from them now. We exchange sensations." (Reina, 1989, p. 54) and despite not feeling saddened and recognizing that she does what she wants to do, she has no other alternative than to confess that deep within herself she feels alone. Through the character of Adi, we see a new generation: a woman who is unattached to the traditional canons, although not because she embodies change is she free from internal suffering, despite the strength that she shows she has.

However, this Adi is the consequence of the passage of time, continuous disappointment, and betrayal. At another time in the past, Adi appears as a naive, candid, defenceless girl in love when one of her brothers made her pregnant, but she was not understood. Her father, even without knowing the truth, laid the blame at her door, something she had not only not forgotten, but she still reproached her father for having done so.

She confessed to Ramon, her brother, talking about the abortion: "I've suffered enough humiliation! From childhood to maturity in twenty minutes, passing through an operating table where a very Catholic surgeon gave me a curettage without an anaesthetic so that it hurt and I wouldn't do it again!" (Reina, 1989, p. 64).

In this paragraph, María Manuela Reina is criticizing illegal abortions, the moral hypocrisy of those who condemned women who had abortions at the same time as profiting from it. Two-faced doctors with no scruples, who took advantage of the situation that women were going through, in this case represented as the victim because of her youthfulness, her lack of resources and experience of life. The question of the paternity of Adi's baby is unresolved in the play, with which María Manuela Reina turns the woman into the star of an unfolding plot. However, unlike what might happen among more traditional cohabitants, Reina never points to Adi as the lost sheep gone astray, but presents her as the victim. She is the visible target of reproach within society, as she was the one who had become pregnant with no known partner and being young, which went against the traditional canons and contributed to her stigmatization. This event marked the personality of Adela, leaving its sequels within her for life, among other reasons, because outside of the closed and arcane circle that her brothers offered her, she had never been able to tell the tale nor had she found relief, therefore, throughout all of her suffering, she was the one who had to live with the accusatorial verdicts of those living around her.

The idea that her beauty is the best card available to a woman for seduction stands out and is not only prominent in this play, but also in others by the dramatist, 
at times essential for the woman to find a partner; as if men would only fix their eyes on appearances or women would only rely on their physique to attract men.

The role that Emilia plays, the mother of Adela, is much more discreet and in accordance with the women of her age. A relation of companionship and complicity is established between Emilia and Adi that has no equivalent between the male members of the family, which is to say, between the father and the sons, and that the shared experience of being a woman reinforces.

A priori Emilia fits the stereotype of a traditional mother and wife: understanding, in charge of everything in her house being in order, always ready to cover all the needs that her family might have. We find her on various occasions in the kitchen, a place from which she discretely watches and listens, traditionally a space associated within the patriarchal model with women. She is unconcerned about her appearance in front of her husband and children, something that for her is now far away in the past. However, it is curious to see how she lays her apron aside upon the arrival of her daughter and "nervously" arranges "her hair". This detail in the stage directions appears to suggest that women are the ones who concern themselves most with caring for their external appearance, playing the coquette and being as dazzling as possible alongside other women, as if it were a sort of code that only they can appreciate in a special way over the years.

\section{The triumph of masculine and feminine energy}

The title of the play comes from the conception that Edward has of life: "Life is a competition and you've got to try and break the finishing line ribbon, to triumph! It's the only prize before the decline." (Reina, 1989, p. 52) and the important thing for him is success: "The only thing that has been important for me in life is success." (Reina, 1989, p. 32). He sums up his stance on life when he says "if you start a race you have to reach the finish line, to get there first." (Reina, 1989, p. 29), a principle that he imposes and demands from his offspring, but with which his children are not all together in agreement. Javier, for example, insists: "That... that's not possible, Dad.", but his father replies: "It is, I have prepared you for that since you were born. And up until now, you haven't let me down." (Reina, 1989, p. 29). On another occasion, it is Ramon who rejects the idea saying, "The fact that there is someone faster than you, doesn't mean that you have no right to race.", to which Edward replies: "We're strong, we've no need for protection. It's what I always tried to drum into you: escape from collectivism and scorn mercy." (Reina, 1989, p. 52), because he thinks that "A life without quality should never be accepted!" (ibid.).

Edward hates weak people, due to this outlook on life, and demands that his children triumph and be strong, that they strive and give their all in everything that they undertake. He imposes it as their duty in life, because in a certain way it appears to him that his children represent it and, as if they were his "property", they have to live and think in accordance with his expectations. An attitude that is a 
cause of frustration for Javier, one example of which is the dialogue that he maintains with his brother Ernest at a certain point in time:

\author{
Ernest: "You were always weak." \\ Javier: "And why do we have to be strong?" \\ Ernest: "I'm sorry to tell you, you're intelligent but mediocre. You never had the mettle \\ needed of a winner." \\ Javier: "True, you all stuck out your chests and broke the finishing line ribbon except me, \\ despite all of Dad's effort." (Reina, 1989, p. 82).
}

In the above dialogue, Ernest appears to share the ideas of his father when reaffirming them, the same Ernest who later rebukes his father: "You asked too much from us (...) We had to be handsome, intelligent, successful with women, reaching responsible jobs ..." (Reina, 1989, p. 21).

Through these dialogues, we can see that María Manuela Reina is inviting us to reflect on the multiplicity of masculine characters and the need not to fall into stereotyping when setting out what it meant to be a man in the society of her time.

Although the stance of the family patriarch is the one that is reflected with respect to his children, it changes diametrically with respect to the expectations of his daughter. Edward has neither invested his hopes for success nor demanded that she triumph, as he has with his male offspring. In fact, it is a reason for reproaching their father, thus Ernest asks him: "But, what ambitions did you have for Adi?" to which Edward replies: "For Adi? She's a woman." and Ernest replies: "You wanted her to be honest, to marry a good man and give you a couple of grandchildren. That would be enough in itself." and Edward simply says: "Any father would subscribe to that for his daughter." (Reina, 1989, p. 21). Here, embodied in Edward, we see the stance of a segment of the population that is perhaps not always shared among the oldest. Its assumption is that success in life has different meanings according to whether people are male or female, in the former case with implications at a sociolaboural, physical and intellectual level. Whereas for women, it is reduced to their role of mother and faithful wife within the family, as if a woman could only find meaning in so far as she had a man at her side to support her.

The rivalry between father and daughter has continued for quite a long time, which in principle appears to be based on Adi's condition as a woman. Among all his children, she is precisely the one who best represents the triumphant profile that Edward only reserves for men, even since she was a young girl and despite the disdain of her father, which leads Adi to rebuke him: "Nobody heard a word of encouragement from you, Dad (...), but I was no Mozart, nor as astounding as Erni, nor as spiritual as Moncho, nor as intelligent as Javier... I was only a girl and I couldn't compete with men." (Reina, 1989, p. 53-54).

Had he acknowledged the worth of her daughter, it might have forced Edward to review his assumptions and to change them, but he is not a man of convictions, which represents a more traditional line of thought and in consequence a reluctance to change. Hence, we observe the following dialogue between Javier and his father: 
Javier: "Adi was the best of your four children. Seriously, Dad, the best. The cleverest, the most dignified...", to which Edward responds: "She lacked resolution. She disappointed me. She was only a woman." (Reina, 1989, p. 31).

In the end, Edward knows that he is mistaken, but his pride stops him from recognizing as much, because Adela had not followed the paths that her father had mapped out for her, she was a woman and she was the only one of his four children who had achieved that success that he desired so much for his male offspring.

\section{Female and male conjugal infidelity}

Within that atmosphere of complicity that exists between mother and daughter, Emilia reveals to Adi, between women, that she was unfaithful to her husband, which might seem unconventional in the case of women of a certain age educated in more conservative ideas, which is the role that Emilia somehow embodies. Less conventional, if possible, is the reaction of Adi to that confession, all the more so if we take into account that her mother has been unfaithful to her father: "Mum, seriously, what a surprise, I'd never have thought so. That's fantastic! You've made me so happy! Let me give you a kiss!" An attitude that also surprises Emilia: "Adi, such emotion! It's not that important ..." to which Adi replies: "I'd say! You've been alive, you've been daring (...)! I'm delighted to know that you did it!" (Reina, 1989 , p. 73). Her conception of infidelity is really quite frivolous. In turn, Emilia acknowledges that it saved her matrimony, because she realized how much she loved her husband, whom she knew had also been unfaithful on numerous occasions. In the play, it is argued that female infidelity does not have to be seen as worse than masculine infidelity, but can be placed at the same level. It might appear that the dramatist is insisting on the view of masculine infidelity as something enviable among other men who do not chase after more women and as something consubstantial with the masculine gender, for which reason, Emilia even says at one point: "The problem of women who are obstinately faithful is that they unable to place themselves in the position of the husband, and that makes them intransigent and unbearable." (Reina, 1989, p. 74). These words conceal a veiled apology of infidelity, seen as a sort of escape valve that is valid and almost necessary within relations. It is almost as if people had to be unfaithful so as not to be intransigent and insufferable, although it is also Emilia herself who admits that adultery is not something of which she could be proud.

Edward, in turn, aware of his advanced age, confesses: "I don't care two hoots about everything now, because I am too close to death, so I can indulge in some sincerity." (Reina, 1989, p. 32), an attitude that led him to confess to Emilia that he had been unfaithful with other women, but Emilia already knew that and it was no surprise to her. The theme picked up here is of the quiet woman, knowledgeable of the adventures of her husband who puts up with and in a certain way accepts that infidelity, because she thinks that it is inherent to men, although the novelty on that point is that she had done the same and she also tries to say so to her husband: "And if I told you that on some occasion, I also met a man and had an adventure with 
him?" to which Edward answers: "You? [Laughs] Get away, Emi, the things that you dream up! I wouldn't believe you." (Reina, 1989, p. 104). We discover, from this conversation that it is therefore not a question of making an open apology for infidelity per se, but of making the audience grasp the idea that is contrary to the themes, counterposing the same attitude both in men and in women to test their ideas and to provoke their revision, considering the arguments wielded by the women.

\section{Matrimony and the traditional masculine and feminine roles}

With the exception of the infidelities that are supposedly a secret between the spouses, the relation between Emilia and Edward is full of confidence. Edward is authoritarian, prickly, intolerant, and loves his wife. She knows all his faults, follows his drift and ironizes on both the behavior and the ideas of her husband to the limit, but without going any further, so that she manages not to make Edward angry. In the words of Jiménez (2018): "she speaks to her husband with irony, but without sarcasm. That irony is a necessary escape value, but with no greater consequences" (p. 98). It is a relation that could be likened to any of those in any Spanish home at that time between older aged people. However, the author in a display of transgression, is not content to bring a sort of matrimony to the stage that the audience can easily recognize in their surroundings, but she also seeks to modify certain aspects that concern the role of women, the view that society has of them and of what their behaviour has to be, so that it is accepted within the bounds of normality.

Thus, Emilia is gracious, ingenious and very realistic, speaks little and intervenes even less than Edward, but when she does so, she balances and soothes tense situations, because she knows at heart that her husband whom she knows how to lead is like "a dog whose bark is worse than his bite". She is less active and more serene than him and, although she apparently adopts the submissive role that society has set aside for married women, she takes control when asked to do so, without any need to have to vaunt it continuously in front of others. Looking at the upper circle, Edward is the one who always has to remain on top of her, as if everything that Emilia does has to depend on him, for which reason he takes decisions that affect them both without consulting her. Something that annoys Emilia and prompts explicit protests from her, because of the disregard in the behavior of her husband. Nevertheless, she finally accepts it, perhaps because she knows deep down that she is the one who decides and she is the one who knows how to treat her husband so that he does what she wants, without him being aware that is the way things are.

Edward is characterized as quite chauvinist and his family knows that is so. In an attempt to express what his father thinks, Ernest says: "women ..., as you know: are unpredictable. You have to excuse them." (Reina, 1989, p.21) and Edward unleashes comments that speak for themselves, such as: "I mistrust women with prodigious buttocks. They bring problems, never fails." (Reina, 1989, p. 28). 


\section{Sex for men and for women}

Adela is aware of the chauvinism of her father, has lived with it and knows how to think, for which reason, she is capable of anticipating it. So, when her father asks her what she is doing, she answers:

Always the same, dad, as you might suspect: the labours of my own sex, I mean, prostitution. But that said, at the top level. You can rest easy (...) But despite everything, I'm sure I don't screw as much as Erni, although I like it as much as him. I'm as immoral because I like it, but he is the one who triumphs and I'm only a whore. (Reina, 1989, p. 53).

Once again, María Manuela Reina brings themes before the audience that, when acted out on stage, provoke the audience to re-examine them and when doing so, by placing the ideas in the mouth of a woman who is the one explaining these ideas that are specific to more traditional masculine thought, it means they are even more shocking and illogical.

From the words of Adela, not only is an explicit criticism evident of that way of thinking, but in addition the idea that sex is also pleasurable for women, at the same time as it can be for men, is likewise asserted. Sex is something that can appeal to both genders to the same extent as it is, in the end, inherent to human beings, which neither makes a woman an impure being, nor less feminine, nor any worse with respect to men.

We find conversations in the play on sex between parents and children, between men and women, and between the same women from the family. Thus, in conversation with his sons, Edward openly speaks of sex; even with his son who is a bishop: "As a man, I suppose that you will continue waking up with stupendous erections, as happened to me up until a little while ago", to which Ramon responds: "Father!" and Edward insists: "Yes or no?". Javier who is also there interjects on the same point: "Curious theological question! Do bishops have erections?". Ernest, also present, adds some urgency to the response of his brother: "We're expectantly waiting. Five seconds to answer.", after which Ramon answers: "Yes." (Reina, 1989, p. 32).

At another time at which the father and sons together with Adela are discussing sex, she says: "I will leave you with your intelligent masculine conversation." (Reina, 1989, p. 50) as if she was rebuking them for speaking of sex in such a banal and futile way.

On another occasion, Adela herself says to her brothers: "I travel, I earn money, I meet interesting men, I often sleep with them.", the view of sex is not necessarily connected with love, at times it appears that greater importance is attached to sex than to love. Adi, at a certain point says to her brother Javier: "Learn from me: over the last 15 years, two marriages, three stable relationships and, in all, five separations." (Reina, 1989, p. 43). This apparent frivolity of Adi is justified in part by the situation, Javier appears dejected because his wife, not him, has decided 
to separate and Adi tries to lessen the importance of the fact, making his brother see that it is something normal that is continuously happening in people's lives. In other words, it is assumed that stable relationships do not have to be the only possible ones. It is curious to observe how at this point it is also the woman, in this case the wife of Javier, who takes up the initiative. We are no longer facing the married women, resigned to living a relationship of no satisfaction to her because of a commitment. That somewhat unjust situation for the man is also covered here. When divorcing he has to give money to the woman, even though he may be insolvent, until she marries again. An unequal situation in which the wife of Javier is portrayed as provocative, full of self-interest, capable of doing anything to achieve what she wants.

A conversation on sex also emerges between Emilia and Adela that is parallel to the one that might have taken place between Edward and his sons. Emilia is in a way fascinated by the independence of her daughter (an independence that she could never enjoy, as it was another era) and the capability of Adi to remain openly in charge of a relationship; it appears fine to her that her daughter utilizes men, although she advises her daughter to act with serenity, not to lose her head over them. Here we find a discourse of the mother towards the younger generation that is comparable to the discourse on women that the father would tell his children, a point which also brings us back to the idea of equal treatment of both men and women, although at times it might appear from the play that it is more a question of treating the woman as if she were a man, extrapolating the chauvinist and mostly worn out discourse that has been perpetuated in the masculine world, so as to make it fit within the female world, by inverting the roles.

\section{Conclusions}

In effect, the work of Reina is one of an dramatist who did indeed manage to connect with the audiences of the day when she wrote her works, The results of the analysis have demonstrated that her work questions representations of traditional worlds in which the social role of the woman is relegated to one of the mother, a faithful, and submissive wife, dependent on her husband. But how does she do so?

Through the analysis we have presented, we can observe that the dramatist covers the situation that the women of her age endured, counterposing different profiles: one more traditional (Emilia's) and another more up to date (Adela's), linked by the vital condition of their status as women.

Reina not only gives a voice to these two types of women, but she breaks with conventional attitudes on the basis of their behaviours and the explanation of their ideas, which very often emerge as a response to others that are set within the male world. When doing so, certain stereotypes may be questioned and calling for the right of women to be valued and seen under equal conditions as men. María Manuela Reina contributed to that, in so far as she was able, so that the spectators at 
that time could, in a sort of internal dialogue, compare the discourse of the characters with their respective models of the world and consider the possibility of restructuring their own ideas on the role that women can play in society.

Not only can we see women of different generations in the play break with the roles that were traditionally expected of them in society, but they also question (although not always) those conventionalisms from the younger masculine sector, in which in many cases they refuse to participate and to identify themselves with such a rigid template of the world.

Reina brings to the stage and thereby counterposes different visions of the world: some influenced by the temporal aspect embodied in people of different generations (fathers and sons) and others influenced by gender represented through male and female characters. But, when doing so, the author never resorts to presenting stagnant and singular models of the world in terms of age and gender, as she allows us to see that not all the people of older generations think and act in accordance with traditional canons, nor can one think that the male view of the world is one, any more so than the female view. In other words, Reina shows the change, the variety of voices on the reality of worlds that are a priori antagonistic (older-younger, male-female) that influence each other reciprocally through dialogue and that may be closer than one might think.

This analysis cannot nor should it be extended to all the plays of this dramatist nor to other contemporaries, although it serves to affirm that there were dramatists throughout those years in which the changing social roles played by women were gathering pace who supported it in their writings, thereby contributing through their responsibility and their commitment to the creation of social awareness that echoed new ideas.

\section{References}

Acuña Luongo, N. \& Valencia Catherine Elisa, A. (2020). Influencia de los estereotipos de género en la comprensión de oraciones. Implicancias para los modelos basados en restricciones.

Revista Signos. Estudios de Lingüística, 54(105), 6-31. Retrieved from: https://scielo.conicyt.cl/pdf/signos/v54n105/0718-0934-signos-54-105-6.pdf

Aguilar, J. Ángel, M. (2018): Crisis del patriarcado en La cinta dorada de María Manuela Reina, in Anagnórosis. Revista de investigación teatral, 17, 79-106. Retrieved from: https://redib.org/Record/oai_articulo1658279-crisis-del-patriarcado-en-la-cintadorada-de-m \%C2\%AA-manuela-reina

Barrientos, G., Luis, J. (2017). Cómo se analiza una obra de teatro: ensayo de método. Síntesis. Madrid

Hernández Sampieri, R.; Fernández Collado, C. \& Baptista Lucio, P. (2010). Metodología de la investigación. Peru: McGraw Hill.

Cabal, F. (1982). Buscando la Puerta del laberinto. Primer Acto, 193, 49-59

Cantero, F. J. \& de Arriba, J. (1997). Psicolingüística del discurso. Lenguaje y comunicación. Barcelona: Octaedro.

Cuetos Vega, F.; González Álvarez, J. \& de Vega Rodríguez, M. (2020): Psicología del lenguaje. Madrid: Panamericana. 2nd edition. 
Matteini Zaccherelli, C. (1998). ¿Qué tienen que decir los jóvenes autores? Voces para el 2000, in Primer Acto. Cuadernos de Investigación Teatral, 272, 6-15.

Ortiz, L. (1995). Los horizontes del teatro español. Nuevas autoras, in Primer Acto. Cuadernos de Investigación Teatral, 258, 11-21.

Reina, M. M. (1989). La cinta dorada. Colección Escena. Madrid. Ediciones MK.

Sánchez Martínez, S. (2005). Aspectos semiológicos en la dramaturgia de Paloma Pedrero. Doctoral thesis, UNED, Madrid.

Santander, P. (2011). ¿Por qué y cómo hacer análisis del discurso? Cinta Moebio, 41, 207-224. Retrieved from:

https://www.researchgate.net/publication/262558710_Por_que_y_como_hacer_Analisis_d e Discurso 